\title{
Object-oriented Information Filtering System for Ubiquitous Environment
}

\author{
Tomoyuki Matsutsuji Non-member (Graduate School of Engineering Science, Osaka University) \\ Yiqun Wang Non-member (Graduate School of Engineering Science, Osaka University) \\ Yoshinori Hijikata Non-member (Graduate School of Engineering Science, Osaka University) \\ Shogo Nishida Member (Graduate School of Engineering Science, Osaka University)
}

Keywords: object-oriented information filtering, ubiquitous environment, PDA, Blog, common sence knowledge base

In the ubiquitous environment, it is important to support people in the real world to get information from the Web. In this paper, we consider the situation that the user walking around the real world makes a decision whether or not he/she uses a geographical facility. We develop a system which displays Blog documents about the geographical facility the user got interested in through the mobile terminal. When we provide information through the mobile terminal, the following problems will occur. One is that the user takes effort to decide whether or not one page includes the required information because of its small screen. The other is that the authors' opinions are not always useful for the user because the information on the Blog is written from various kinds of viewpoint. Even if the Blog includes positive opinion, the author did not use the facilities in the same objective as the user.

In this research, we search Blogs on the Web by using not only the facilitiy's name but the keyword about the user's objective. For decreasing the user's effort for inputting the objective, we show candidates of objective by list. For decreasing the user's effort for browsing documents, we only show the text part which exists around the keyword of the objective.

For acquiring candidates of objectives, we use a common sense database called "Open Mind". People around the world can input common senses in natural language. We acquire objectives from this database in the form of "verb - noun". When we acquire verbs and nouns from the database, synonyms are included in them. We consolidate these synonyms in one word by using a dictionary. We develop a template for extracting the set of verb and nouns about the objective from Open Mind. The created templates are shown in Table 1.

We use commercial Blog search engine for obtaining a Blog page. The system inputs a query including the name of facility and verb and noun representing the objective after the user selects one of the objectives shown to the user. Note that synonyms are supplemented for the objectives. The system identifies the Blog documents which write about the facility
Table 1. Evaluation results of templates

\begin{tabular}{|c|c|c|}
\hline Template & $\begin{array}{c}\text { Prec. } \\
(\%)\end{array}$ & $\begin{array}{c}\text { Rec. } \\
(\%)\end{array}$ \\
\hline $\begin{array}{c}\text { if you want to VP NP } \\
\text { then you should go to }\langle\text { term }\rangle .\end{array}$ & 95.9 & 19.2 \\
\hline $\begin{array}{c}\text { you can use }\langle\text { term }\rangle \text { to VP NP. } \\
\text { (going to) }\langle\text { term }\rangle \text { is for VPL NP. } \\
\langle\text { term }\rangle \text { is (used) for VPL NP. }\end{array}$ & 94.7 & 7.3 \\
\hline going to) $\langle$ term is for people to VP NP. & 96.4 & 33.1 \\
\hline people (can) VP NP [in, at, on] $\langle$ term $\rangle$. & 58.6 & 6.9 \\
\hline $\begin{array}{c}\langle\text { term }\rangle \text { is a place to VP NP. } \\
\langle\text { term }\rangle \text { is (a place) where VP NP. }\end{array}$ & 75.0 & 3.7 \\
\hline Average & 89.6 & 74.3 \\
\hline
\end{tabular}

Prec.: Precision Rec.: Recall

and extract the text surrounding the keyword of the objective. We use DOM structure on the Web page for extracting the surrounding text.

We conducted an experiment to evaluate the accuracy of the templates and the user's confidence and effort for making a decision by using the system. The precision and recall of the template are shown in Table 1 . We can see that the templates acquire the objective in high precision. The recall is smaller than precision. However the user might be annoyed when many errors are shown in the small screen. We compare our proposed system with a system only providing an IF of Blog search Engine (Technorati), a system using the input interface of our system and the output interface of Blog search Engine (Technorati $(\mathrm{Obj})$ ), a system displaying snippets instead of the surrounding text of the objective (Snippet) and a system displaying full text of the Blog page instead of the surrounding text of the objective (Full). We obtained the user's confidence and effort in five degree. The result is that the proposed system is better than Technorati, Technorati $(\mathrm{Obj})$ and Full in both of confidence and effort. The proposed system is the best in confidence. The effort of Snippet is better than that of the proposed system. However the difference is small. The overall result is the proposed system can help users walinkg aroung the real world. 


\title{
ユビキタス環境における目的指向型フィルタリングシステム
}

\author{
非会員 松辻 智之* 非会員 王 軼群* \\ 非会員 土方 嘉徳* 正 員 西田 正吾*
}

\author{
Object-oriented Information Filtering System for Ubiquitous Environment
}

Tomoyuki Matsutsuji*, Non-member, Yiqun Wang*, Non-member, Yoshinori Hijikata*, Non-member, Shogo Nishida*, Member

In the ubiquitous environment, it becomes important to support people who move in the real world to get information from the Web. In this paper, we consider the situation that the user walking around the real world makes a decision whether or not he/she uses a geographical facility. We develop a system which displays Blog documents about the geographical facility the user got interested in through the mobile terminal. The system searches Blogs on the Web by using not only the facility' s name but the keyword about the user's objective. The user just selects the user's objective from the candidates created from common sense database. The system extracts the surrounding text of the selected objective from the Blog documents for decreasing the quantity of the information for the user. The evaluation showed that the system can improve the user's confidence of the decision and decrease the user's effort when he/she has to make a decision in short time.

キーワード : 目的指向型フィルタリング, ユビキタス環境, 携帯端末, Blog, 常識データベース

Keywords: object-oriented information filtering, ubiquitous environment, PDA, Blog, common sence knowledge base

\section{1.はじめに}

近年，通信技術の発展により，いつでもどこでもネット ワーク上の情報にアクセス可能なユビキタス環境が現実と なりつつある。このような環境では, 実世界を移動してい るユーザに対する情報獲得支援が重要な機能の一つである と言われている(1)。実世界を移動するユーザは, 明確な目 的を持ち移動するユーザと, 明確な目的を持たずに移動す るユーザの 2 種類に分類できる。

前者は仕事で相手先の会社に行くユーザのような，行き 先や使う交通機関などが事前にわかっているユーザである。 後者は市街地を散策しているユーザのような, その場で興 味を持った施設を利用し，事前にどこで何をするかを明確 には決めていないユーザである。それぞれのユーザが情報 獲得する状況を考えると, 前者は, 相手先の会社や利用す る駅など，利用する施設が確定しているため，事前に机上 で情報を獲得することが可能である。一方，後者は，散策 中など移動の最中に利用する施設を決定するため, 事前に

\footnotetext{
* 大阪大学大学院基礎工学研究科

干 560-8531 大阪府豊中市待兼山町 1-3

Graduate School of Engineering Science, Osaka University

1-3, Machikaneyama, Toyonaka-shi, Osaka 560-8531
}

その施設に関する情報を獲得することが不可能であり，そ の場で情報獲得をしなければならない。例えば，仕事帰り に仲間とお酒を飲むのに繁華街に出てきたとする。ちょう ど目の前に雲囲気の良い居酒屋があるが，本当に美味しい 店なのかは概観からはわからない。この店に入るか, それ とも違う店を探すのかを意思決定しないといけないような 状況である。

そこで我々は，散策中のユーザを対象に，ある地理施設 に関して，Web上の情報，特にB $\log$ の情報を容易に獲得 するためのシステムを考える。Blog は個人が自由に書くこ とができるため, 施設を利用した際の評価や実際の体験談 が書かれていることが期待できる。このような情報は, 実 世界を散策中のユーザがその場で獲得することが困難であ り，その施設を利用するかどうかを判断するために有用な 情報であると考えられる。

一般に Web 上の情報を獲得するには，ユーザは自分の 要求を検索クエリとして表現し, それを検索エンジンに入 力する。そして, 検索結果として得られるページ中から自 分の要求に合った情報を探す。しかし，実世界を散策中の ユーザがこのプロセスで $\operatorname{Blog}$ から情報を獲得しようとす ると，次のような問題を生じる。

実世界を散策中のユーザが情報獲得を行うには，携带電 
話やPDAのような携帯端末を用いる必要がある。しかし， 携帯端末は画面が小さいため, 検索結果の中から多くのペー ジに移動して，それらのページ中に求める情報が含まれて いるかを判定することは困難である。また, 一般にB $\log$ 上 の情報は非常に多様な観点から書かれている。たとえば，同 じ喫茶店について書かれた Blogでも，そこで恋人と話を する目的で利用したユーザが書いた B log と, 一人で仕事 をする目的で利用したユーザが書いた Blogでは，書かれ る内容が異なる。検索を行うユーザにも，そのユーザの目 的があるため（ユーザは目的を意識していない場合もある と思われるが), どちらの Blogも同じように重要とは限ら ない。しかし，その契茶店の名称のみを検索クエリとして 検索を行うと, この両方の $\operatorname{Blog}$ が検索結果として表示さ れてしまい, ユーザは携帯端末の小さな画面でこの検索結 果から自身の目的に合う情報を探さなければならなくなる。

これを解消するには，ユーザの目的に関するキーワード も検索クエリに加えて，検索を行うことが考えられる。し かし，携帯端末 (特に携帯電話) の入力デバイスは文字入力 が困難であり，長い検索クエリを入力させることは，ユー ザに負担を強いてしまう。さらに散策中のユーザは，その 日の行動に明確な目的を持っていないことも多い。そのよ うなユーザにとっては，自発的に自身の目的を明示化し，そ れをキーワードとして表現することは困難と思われる。

本研究の目的は，ユーザがある地理施設の情報を Blog から獲得する際に，そのユーザの目的に合った情報を持つ B log ページのみを発見する目的指向の情報フィルタリング システムを開発することにある。本研究では，ユーザの目 的を入力する負荷を低減するために，ユーザが興味を持っ た施設に応じた利用目的を選択肢として提示することとす る。これによりユーザはカーソルキー（あるいは十字キー） のみで，自身の目的を入力することができるようになる。 そして，ユーザの情報を閲覧する負荷を低減するために， Blog 全文ではなくユーザから獲得した利用目的に関連した テキスト部分のみを提示することとする。

本稿の構成は, まず 2 章で本研究のアプローチについて 述べ，次に 3 章ではシステム全体の構成について述べる。 そして，4章では，目的指向な情報フィルタリングを実装 するための具体的な方法について説明し，5章で実装した システムの評価実験を行う。6 章で関連研究について述べ, 7 章で本稿のまとめと今後の課題について述べる。

\section{2. アプローチ}

本システムは，ユーザの地理施設に関する利用目的を獲 得し，その利用目的を用いて情報フィルタリングを行う。本 章では，まずユーザから利用目的を獲得するアプローチに ついて説明し，次に情報フィルタリングにユーザの利用目 的を用いるためのアプローチについて説明する。

〈2・1〉 ユーザからの利用目的の獲得 本節ではユー ザが興味を持った地理施設での，ユーザのその施設での利 用目的をどのようにして獲得するかについて説明する。 $\langle\mathbf{2} \cdot \mathbf{1} \cdot \mathbf{1}\rangle$ 目的獲得手法の分類一般にユーザから目 的を獲得するには, 明示的にアンケートを取る方法（明示 的手法) (2) と, ユーザの何らかの操作ログなどから自動推 定する方法 (暗黙的手法) (3) (7) が挙げられる。

明示的手法は，ユーザに目的を直接に入力してもらう手 法と, ユーザに目的の選択肢を提示し，その中から回答し てもらう手法の 2 種類がある。前者は, 直接に目的を文字 入力しなければならず, 入力の負荷が大きい。後者は, 回 答を選択する操作は必要ではあるが, 直接入力ほど煩雑な 操作ではなく，簡単な操作で目的の入力が可能である。

暗黙的手法は，ユーザに入力の手間をかけないという利 点がある。しかし, ユーザの目的を推定により求めるため, エラーが混入する可能性がある。さらに, 散策をしている ユーザのように気まぐれな行動をとるユーザを対象とした 場合は，その目的の推定が難しくなる問題もある。

本研究では，ユーザの入力負荷の少なさと目的獲得の正 確さを考慮して，ユーザの利用目的の獲得には明示的手法 で選択肢を提示する方法を適用する。具体的には施設の利 用目的の候補を事前に獲得しておき，ユーザが興味を持っ た施設を明示すれば，その施設に応じた利用目的を選択肢 としてユーザに提示する方法をとる。

$\langle\mathbf{2} \cdot \mathbf{1} \cdot \mathbf{2}\rangle \quad$ 選択肢となる利用目的の獲得 施設の利用 目的を獲得する単純な方法としては，施設の利用目的を人 手で収集, 整理する方法が考えられる。しかし, この方法 では, 個々の施設に対して利用目的を網羅的に調査し, そ れらを整理するという膨大な作業を強いられてしまう。ゆ えに, 利用目的の収集, 整理は, 既存に明示されている情 報源を用いて自動的に行われることが望ましい。

選択肢となる利用目的を収集するための既存の知識源と して，以下の 3 種類の情報源が挙げられる。

(1) Web

Web 全体を対象として, 地理施設の利用目的を 収集することが考えられる。ある施設名が存在する Web ページを獲得することは容易である。しかし, それらのページはレイアウトも表現のスタイルも様々 であるため，その中から利用目的に関する情報を抽 出することは困難である。

(2) 百科事典

電子化された百科事典にも，地理施設の利用目的 に関する情報は含まれる。しかも, Web 全体のペー ジを対象とする場合と比べ, 記述される文脈が多様 ではなく，さらに記述される形式も統一されている。 しかし，そこに記述される内容は百科事典の著者の 定義に基づいたものに限られるため, 多くの利用目 的を網羅的に収集することができない。

（3）常識データベース

近年, 社会における様々な人間の常識をデータベー ス化するという試みが, “Cyc project” (8) や“Open Mind”(9) などのプロジェクトで行われている。これ らのプロジェクトでは, 多くのユーザが協力して知 
識を入力することを前提としている。特に, Open Mind は, 誰もが Web を通して入力でき, 特殊な知 識表現形式ではなく自然言語で入力できる。2009 年 5 月時点で約 75 万ユニットもの常識が獲得されてい る。また自然言語ではあるが，比較的決まった言い 回しが多いという特徴を持つため, Web 全体を対象 とするよりは構造化された知識を抽出することが容 易である。

これらを比較したときに，(3) 常識データベース，特に Open Mind は, 知識の抽出の容易さとその知識の多様性の 観点から，本研究に扔ける施設の利用目的を収集するのに 適した情報源と思われる。そこで本研究では，Open Mind を利用してユーザに提示する利用目的の選択肢を作成する こととする。ただし，Open Mind には全ての個々の施設 に対する常識が記述されているとは考えられないので, 利 用目的を施設の種類ごとに収集することとする。

$\langle\mathbf{2} \cdot \mathbf{2}\rangle$ 利用目的を用いた情報フィルタリング 一般に Web 上の情報を獲得するには, 検索クエリを検索エンジン に入力し，検索結果のページを閲覧する。そして，リンク されているページの中から自分の要求に合っているページ を探し，そのページに移動する。これを繰り返し，自分の 要求に合う情報を獲得する。しかし, 携带端末で情報検索 を行うユーザは，検索結果のスニペットを詳しく読み，検 索結果のうちのわずかな数のページにしか移動していない ことが報告されている(10)。これは，携帯端末はデスクトッ プに比べて, 情報獲得の作業環境が劣徳であることが原因 であると考える。携带端末を使用する状況は，ゆっくり席 に座っているとは限らない。また，ネットワークの通信速 度も遅く、リンクのクリックごとにパケット代もかかって しまう。さらに、リンク先の長文を携带端末の小さな画面 内で表示し，閲覽するには負荷がかかってしまう。これら の環境が、リンク先の本文の閲覽に支障をきたしているも のと思われる。

しかし，現在のスニペットは，リンク先の Web ページ 中から検索クエリを含むテキスト部分を検索クエリの前後 の数単語を強制的に抽出している。そのため, 実際にどの ようなことが書かれているかは（特にスニペットの前後の 文脈を把握するためには), リンク先の Web ページに移動 しなければわからないことが多い。そこで本システムでは, 検索結果のスニペットをより意味を理解しやすい文章と置 き換えることを目指す。意味的に理解可能な文章を表示す ることで，各 Blog ページに移動せずに，自分の利用目的 に関連する部分のみを閲覧することが可能となる。ユーザ にとっては短時間での情報獲得が期待できる。

本システムでは，ユーザが興味を持った施設の名称とそ の施設に関する利用目的を用いて 2 段階の情報フィルタリ ングを行う。具体的には，まずユーザの利用目的にあった Blog を得るために, 施設の名称と利用目的を基にした検索 クエリを作成し，商用の検索エンジンを用いて検索を行う。 Blog の情報を検索するためには, Blog 用の検索エンジン
を独自に実装するか, 商用で提供されている Blog 用の検 索エンジンを用いるかが考えられるが, 実装コストの低さ と検索エンジンの性能の高さを考慮して, 商用の検索エン ジンを用いることとする。

次に，その検索クエリにより得られた検索結果のページ からリンクされている各 Blog ページから, その地理施設 について書かれている記事を特定し, さらに利用目的の周 辺のテキスト部分を抽出する。我々は先行研究でアンカー (リンクが張られたテキスト部分のこと) 周辺のテキスト で，そのアンカーのリンク先の内容に関連する部分がどこ にあるのかを調査し，その調查結果に基づいたアンカー関 連部分の抽出方法を提案した ${ }^{(11)}$ 。本研究では, この抽出方 法を, 利用目的の周辺のテキスト部分の抽出に応用する。 以降では, 利用目的周辺のテキスト部分を“NRT (Nearest related text)”と呼ぶこととする。

\section{3. システム構成}

本章では，まず本システムの利用方法について説明する。 次に本システム全体の構成を述べ, 処理の流れの順に各モ ジュールの具体的な動作について述べる。

$\langle\mathbf{3} \cdot \mathbf{1}\rangle$ 利用方法 提案するシステムでは, 次のよう なユーザの状況で用いられることを想定している。以下で は，その状況とその状況に扔いての利用方法について説明 する。

ユーザが実世界を散策している時に，ある施設に興味を 持ち，そこを利用するかどうか考えているとする。そこで ユーザは本システムにアクセスし, 同時に携帯端末からユー ザの位置情報をシステムに送信する。すると，携帯端末の 画面にはユーザの周辺にある施設の一覧が表示される（図 1左)。ユーザがその中から興味を持った施設を選択すると, 次に選択した施設の種類に応じた利用目的が選択肢として 表示される (図 1 中央)。ユーザが選択肢の中から自分の利 用目的を選べば，携帯端末の画面に施設名と利用目的によ り情報フイルタリングされた結果が表示される(図 1 右)。 ユーザからの入力インタフェースには, 十字キーと決定ボ タンのみを想定している。そのため, 携带端末には携帯電 話も利用可能である。

〈3・2〉 システム構成本研究で提案するシステムの 構成を図 2 に示す。本システムは, 「周辺情報獲得モジュー ル (Neighborhood acquisition module) 」,「利用目的獲得
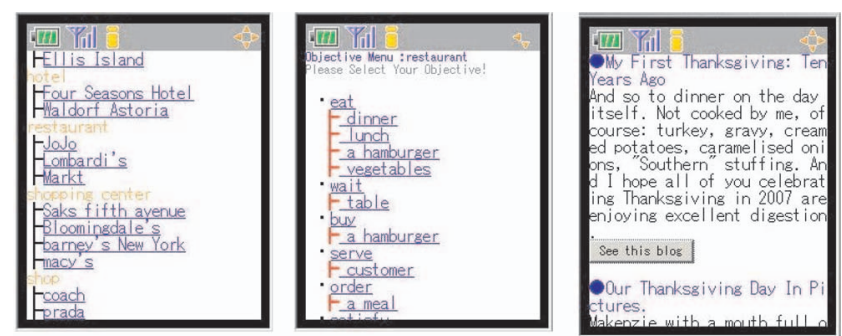

Fig. 1. Screenshots of our system 


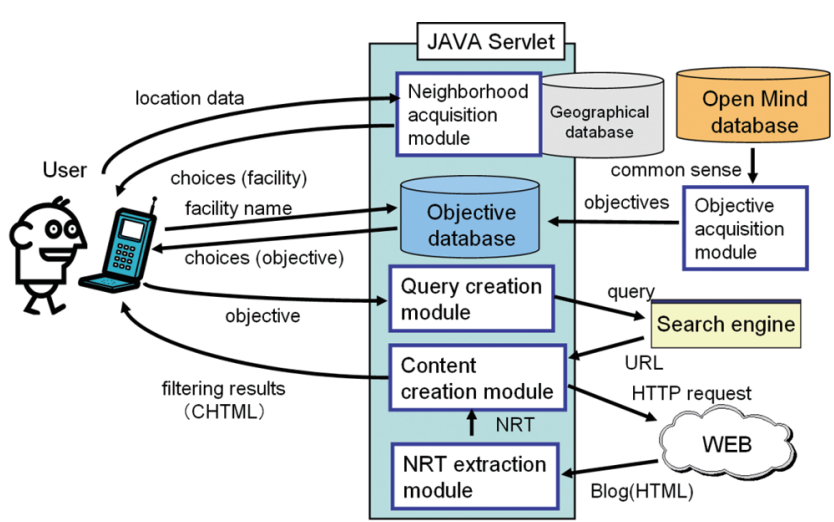

Fig. 2. System structure

モジュール (Objective acquisition module)」,「検索クエ リ生成モジュール (Query creation module)」,「NRT 抽出 モジュール (NRT extraction module)」,「コンテンツ作成 モジュール (Content creation module)」から構成される。 クライアントの端末とのやり取りは Java サーブレットで 行う。以下では, 本システムが処理を行う順に各モジュー ルの機能を説明する。

利用目的獲得モジュールは, 事前に Open Mind から各施 設の種類ごとに利用目的を獲得し，それらを利用目的デー タベースに格納するためのモジュールである。獲得した利用 目的は，施設の種類名をキーとしてデータベースに格納さ れる。本モジュールについては 4 章でより詳しく説明する。

周辺情報獲得モジュールは，ユーザから送信された位 置情報を基に,「地理情報データベース (Geographical database)」にアクセスし，ユーザ周辺にある地理施設の 名称とその施設の種類名を獲得するモジュールである。こ のモジュールを実現するためには，GPS などの絶対位置計 測技術を用いてユーザの位置情報を獲得し，GML ${ }^{(13)}$ など で記述された地理情報データベースにアクセスし，上記情 報を獲得する方法が考えられる。本モジュールは，地理施 設に関する情報を含んだ地理情報データベースが獲得でき れば実現できる（ただし，地理情報データベースが適切な API を備えていることが前提である)。しかし，本研究で は施設の利用目的を獲得するのに OpenMind を使用して いるが，OpenMind の使用言語は英語である。実装したシ ステムの評価を行うには米国の都市を対象として実験を行 う必要がある。我々の調査した範囲内では，米国の都市を 対象範囲とした適切な地理情報データベースを取得するこ とはできなかった。そこで, 実装したシステムでは, 施設 名と施設の種類名を持った地理情報データベースを独自に 定義し，それを使い施設情報を獲得するモジュールを作成 している。

検索クエリ生成モジュールは，ユーザが選択した施設の名 称と利用目的を基に, 検索クエリを生成するためのモジュー ルである。本モジュールについては 4 章でより詳しく説明 する。

NRT 抽出モジュールは，Blog ページから利用目的に関
連する NRT を獲得するモジュールである。Blogでは, 1 ページに複数の Blog 記事が列挙されていることが多い。本 モジュールは, Blog ページから個別の記事を元の HTML の構造を含めて抽出する。さらに，抽出した個別の記事の 中から地理施設の名称を含む記事を特定する。最後に，そ の記事中の HTML の構造を解析し, 利用目的に関連する NRT を獲得する。NRT の獲得方法については 4 章でより 詳しく説明する。

コンテンツ作成モジュールは，検索エンジンが出力する 検索結果のランキングと NRT 抽出モジュールが獲得した NRT を用いて, ユーザの携帯端末に表示可能な HTML ソースを作成するためのモジュールである。携带端末の小 さな画面でも効率的に情報を表示できるようにタイトルと NRT だけを表示することとした。記述言語には, Compact HTML ${ }^{(15)}$ を用いた。

検索エンジンには, 商用の Blog 検索エンジンである Technorati ${ }^{(16)}$ を用いた。 4 章にて説明するが, 利用目的獲 得モジュールと検索クエリ生成モジュールでは, 辞書を用 いている。この辞書には, オンラインの辞書 ${ }^{(14)}$ を用いた。

\section{4. 利用目的の獲得と情報のフィルタリング}

本章では，まず利用目的獲得モジュールを作成するため に Open Mind から利用目的を獲得する方法について説明 し, 次に Blog ページを検索する方法と, 検索結果として 出力された各 Blog ページから利用目的周辺のテキスト部 分を抽出する方法について説明する。

$\langle\mathbf{4} \cdot \mathbf{1}\rangle$ 利用目的の獲得 ユーザに提示する利用目的 を OpenMind から獲得する方法について述べる。利用目 的はその施設で「何かをする」という形式で表現されるた め, Open Mind から利用目的を抽出する際は, 「動詞 $\rightarrow$ 名 詞句」の構造を単位とする。

Open Mind に抢ける常識の入力画面には, 事前に登録 されている常識をユーザに提示し，その常識に関連のある 常識の入力を促している。その結果, 提示された常識の一 部分だけを変えた同じ形式の文章が多く登録されている。 例をあげると, “There are tables in restaurants."という 常識が提示された時に “There are chairs in restaurants." のように名詞を 1 つだけ置き換えた常識が入力されるよう な場合がある。

一方，一般に自然言語で書かれた文書からある記述を抽 出するためのテンプレートを作成する方法には，(i) 人間 がそのテンプレートを定義する方法と, (ii) 教師信号によ りテンプレートを学習する方法がある。Open Mindには, 前述のように格納されている常識に似た形式の文が多いと いう特徵があるため, 人手でいくつかのテンプレートを定 義するだけでも十分に精度よく利用目的の記述を抽出でき ると考えられる。そこで我々は, Open Mind 内の施設に 関する常識の中で, その施設の利用目的に関する記述のあ る文 (以下, 目的系の文) を調查し, 動詞 $\rightarrow$ 名詞句の形で 利用目的を抽出するためのテンプレートを人手で作成する 
こととした。

我々はまず, Open Mind 内の目的系の文がどのような文 構造になっているか調査するため, 6 種類の施設に関する常 識を最大 100 件獲得し，それらが目的系の文であるか，そう でないかを判定した。6 種類の施設名には, “air port”, “city hall", "gallery", "station", "temple", "theme park" を 用いた。

具体的には施設名を文中に含む常識を Open Mind から 獲得し, それを 3 名の調査員が 1 件ずつチェックしていき, 2 人以上が目的系の文と判断した場合に，その常識を目的 系の文とした。その結果，456 件の常識中には 99 件の目的 系の文が存在していた。そして，それら 99 件の目的系の文 について共通する特徴を調べ, 動詞 $\rightarrow$ 名詞句の形を抽出 できるよう，テンプレートを作成した。

そのテンプレートを表 1 に示す。表でのテンプレート の書式は次の通りである。 $\langle$ term $\rangle$ が 地理施設の種類名, $V P$ は目的系の文の動詞, $V P L$ は目的系の文の動名詞, そ してNPはその動詞に続いた名詞句を表している。この $V P(V P L), N P$ が抽出する利用目的となる。例えば，“a city hall is for paying traffic tickets”という常識があった とすると, この文は $\mathrm{ID}=3$ のテンプレートに当てはまる。

本システムでは, 収集した利用目的を選択肢としてユー ザに提示する際には，ユーザの閲覧性の高さを考慮して， 抽出した利用目的を動詞ごとにまとめた「動詞 一名詞句」 の階層構造を採ることとする。これは, 利用目的の主要な 意味は動作，すなわち動詞で表されると考えられるためで ある。また，さらなる詳細については，動詞の後の目的語 で特定できると考えられるためである。さらに，収集した 利用目的の中には，互いに類義語の関係であるものが含ま れることが考えられる。これらは同じ利用目的を意味して いても異なる選択肢として提示されてしまう。そこで，利 用目的を収集する際に，辞書により同義の利用目的を一つ の選択肢に集約し，表示することとする。

〈4·2〉 情報フィルタリングの方式ここでは, 本シス テムが用いる情報フィルタリングの方式において，検索ク エリの作成方法と, $B \log$ 記事から利用目的周辺のテキスト 部分を抽出する方法について述べる。

利用目的は，動詞と名詞句から構成されるが，それらを 検索クエリに含める方法を考える。一般に動詞には, いく

Table 1. Template pattern

\begin{tabular}{|c|c|}
\hline ID & Template \\
\hline 1 & $\begin{array}{c}\text { if you want to VP NP } \\
\text { then you should go to }\langle\text { term }\rangle .\end{array}$ \\
\hline 2 & you can use $\langle$ term $\rangle$ to VP NP. \\
\hline 3 & $\begin{array}{c}\text { going to) }\langle\text { term }\rangle \text { is for people to VP NP. } \\
\text { (going to) }\langle\text { term }\rangle \text { is for VPL NP. } \\
\langle\text { term }\rangle \text { is (used) for VPL NP. }\end{array}$ \\
\hline 4 & you would go to $\langle$ term $\rangle$ because you VP NP. \\
\hline 5 & people (can) VP NP [in, at, on] $\langle$ term $\rangle$. \\
\hline 6 & $\langle$ term $\rangle$ is a place to VP NP. \\
& $\langle$ term $\rangle$ is (a place) where VP NP. \\
\hline
\end{tabular}

つかの活用形（現在形や過去形など）が存在する。そこで, Web 上で提供されている辞書から利用目的の動詞の活用形 を獲得する。また，選択肢を作成する際に，類義語を 1 つの 単語に集約していたため, ユーザが選択した利用目的（動 詞と名詞）の類義語を補完する。これらの語と AND, OR の検索オペレータを用いて検索クエリを作成する。

Blog 記事から利用目的周辺のテキスト部分（NRT）を 抽出する方法を考える。我々は先行研究でアンカー（リン クが張られたテキスト部分のこと）周辺のテキストで，そ のアンカーのリンク先の内容に関連する部分がどこにある

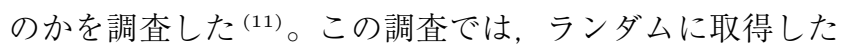
約 1000 ページに対して, 3 人の評価者の多数決で, リン ク先の Web ページの内容に関連するテキスト部分を特定 した。特定されたテキスト部分とそうでない部分の境界に ついて調べたところ, DOM 構造 ${ }^{(12)}$ (Web の標準化団体 である W3Cにより策定された, Web ページの構造化手法 とプログラムからのアクセス方法に関する標準）を見るた けで, 約 $95 \%$ の精度で自動抽出が可能なことを確認した。 本研究では, 利用目的のキーワードをアンカーとみなして, 同じようにDOM 構造を見ることでNRT を抽出し，それ をフィルタリング結果としてユーザに提示することとする。

本システムにおける, NRT の抽出方法の詳細を述べる。 Blog は, 文章を主体として記述されるため, 多くの場合改 行で区切って, 複数の段落から構成されている場合が多い。 我々の調査した範囲内では，この区切りを実現するのに，二 通りの方法があることがわかった。一つは, 構造型文書に おける親オブジェクト（paretnt node）を用いる場合であ る。具体的には，あるキーワードを含む段落は，〈P>タグ (HTML においても段落の区切りとして定義されている) またはくDIV>タグ（HTML では要素をまとめる夕グとして 定義されており，これにCSS を適用することで段落を装飾 的に実現することが多い) で区切られる。もう一つは，構 造型文書における兄弟オブジェクト（sibling node）を用 いる場合である。具体的には，あるキーワードを含む段落 は，その前後にある 2 つ上連続するくBR>タグで区切られ る。<BR>タグが 2 つ以上連続しない場合は, 単に行揃えの ために用いられていることが多く, 段落とみなされること はほとんどない。

本抽出手法では, 利用目的に関するキーワードの存在す る位置を特定する。そこから，まず周辺の sibling nodeを 探索する（文書の先頭方向と末尾方向の両方に探索する）。 sibling node を発見すれば，それがくBR>タグかどうかを調 べる。<BR>タグであれば，さらにその外側にある sibling node が<BR>タグかどうかを調べる。<BR>タグが連続して いれば，それを境界とみなす。

上記の処理により，2つ以上連続するくBR>タグが発見さ れなければ, その parent node を探索する。 parent node がくP>夕グか<DIV >夕グであるかどうかを調べる。<P>夕 グか $<\mathrm{DIV}>$ タグであれば，それを境界とみなす。<P $>$ タグ かくDIV>タグでなければ，さらに上位階層の parent node 


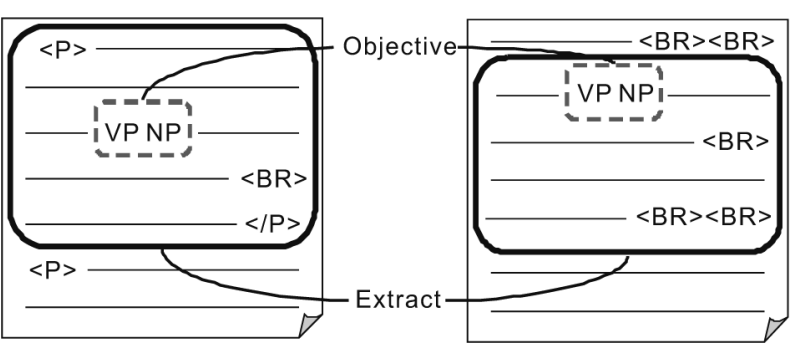

Fig. 3. Examples for extracting NRTs

を探索し, 同様の処理を繰り返す。

図 3 に，上記手法による抽出例を示す。

\section{5. 実 験}

本システムの評価をするにあたり， 2 種類の実験を行う。 まず, Open Mind から利用目的を獲得するためのテンプ レートの評価実験を行う。次に，提案システムと比較用に

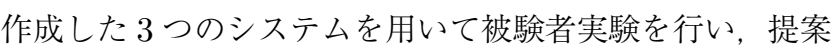
するシステムの有効性を検証する。なお, NRT の抽出精度 に関する評価は, 先行研究にてアンカー関連テキストの抽 出が高い精度で実現できているため (4.2 節参照) 省略する ことし, 商用の Blog 検索エンジンが出力するスニペット （他，2つのコンテンツ）とどちらが意思決定に有効であっ たのかを後者のシステム全体評価で確認する。

〈5・1〉 テンプレート評価実験 15 種類の施設の種類 に対して，OpenMind からそれに関する常識を収集した。 収集した常識からランダムに 100 件を抽出した。一つ一つ の常識に対して，3名の調査者により多数決で正解デー夕 を付与してもらった。上記の 1500 件の常識に対してテン プレートを適用し, 正解データと比較することで, 抽出の 精度と再現率を求めた。

施設の種類としては, “cafe", "casino", "church", "department store", "gallery", "gym", "hotel", "library", "movie theater", "museum", "restaurant", "shopping mall", "stadium", “university”を取り上げた。

精度の定義は，各テンプレートが抽出した利用目的のう ち，本当に利用目的を表していたものの割合となる。再現 率の定義は, 1500 件の全常識中に含まれる利用目的のうち, 各テンプレートにより抽出できた割合となる。

結果を表 2 に示す。この結果より，作成したテンプレー 卜はOpenMind 内の施設名を含む常識であれば，そこか ら約 $90 \%$ の精度で利用目的を獲得可能であるといえる。ど の程度の精度で有用なのかについては判断が難しい。5 章 で行った実験においては，ユーザは，中には利用目的とは 言えない項目はあるものの無視できる範囲内のようで, 利 用目的の選択に難しさを感じている様子はなかった。一方, 精度に比べると再現率は約 $74 \%$ と低くなっている。本シス テムでは携带端末に利用目的を提示するため, 低い精度で 大量の利用目的を提示されると不便であると思われる。テ ンプレートの適合条件を緩くすれば，再現率を上げること ができるが, 代わりに精度は落ちてしまう。本システムで
Table 2. Evaluation results of templates

\begin{tabular}{|c|c|c|}
\hline Template ID & Precision (\%) & Recall (\%) \\
\hline 1 & 95.9 & 19.2 \\
\hline 2 & 94.7 & 7.3 \\
\hline 3 & 96.4 & 33.1 \\
\hline 4 & 100.0 & 3.7 \\
\hline 5 & 58.6 & 6.9 \\
\hline 6 & 75.0 & 3.7 \\
\hline Average & 89.6 & 74.3 \\
\hline
\end{tabular}

\begin{tabular}{|c|c|c|}
\hline$<$ Round $1>$ & $<$ Round 2> & $<$ Round 3 $>$ \\
\hline $\begin{array}{l}\text { Hotel } 1 \\
\text { - SOHO Grand Hotel } \\
\text { - Waldorf Asotoria } \\
\text { - Four Seasons Hotel }\end{array}$ & $\begin{array}{l}\text { Restaurant } 3 \\
\text { - Mezzogiorno } \\
\text { - Penang } \\
\text { - Twilo }\end{array}$ & $\begin{array}{l}\text { Museum } 2 \\
\text { - Jewish Museum } \\
\text { - Cooper Hewitt Nationa } \\
\text { Design Museum } \\
\text { - American Folk Art }\end{array}$ \\
\hline Museum 1 & Shop 2 & Museum \\
\hline - Frick Collection & - macy's & \\
\hline - New York Historical & - barney's New York & Restaurant 5 \\
\hline Society & -Saks fifth avenue & - Canteen \\
\hline $\begin{array}{l}\text { - American Museum of } \\
\text { Natural History }\end{array}$ & $\begin{array}{l}\text { Church } \\
\text { - Cathedral of St. John }\end{array}$ & $\begin{array}{l}\text { - planet Hollywood } \\
\text { - espn Zone }\end{array}$ \\
\hline $\begin{array}{l}\text { Restaurant } 1 \\
\text { - serafina } \\
\text { - Lombardi's } \\
\text { - Hooters }\end{array}$ & $\begin{array}{l}\text { the Divine } \\
\text { - Trinity Church } \\
\text { - Riverside Church }\end{array}$ & $\begin{array}{l}\text { Restaurant } 6 \\
\text { - Aquavit } \\
\text { - Atelier } \\
\text { - el faro }\end{array}$ \\
\hline $\begin{array}{l}\text { Shop } 1 \\
\text { - whole foods market } \\
\text { - NBA store } \\
\text { - the Disney store }\end{array}$ & $\begin{array}{l}\text { Hotel } 2 \\
\text { - Hotel Pennsylvania } \\
\text { - Gramercy Park Hotel } \\
\text { - Hotel Chelsea }\end{array}$ & $\begin{array}{l}\text { Park } \\
\text { - Battery Park } \\
\text { - Ellis Island } \\
\text { - Central Park }\end{array}$ \\
\hline $\begin{array}{l}\text { Restaurant } 2 \\
\text { - the Odeon } \\
\text { - Hard Rock cafe } \\
\text { - Blue Ribbon }\end{array}$ & $\begin{array}{l}\text { Restaurant } 4 \\
\text { - Markt } \\
\text { - Tabla } \\
\text { - Atelier }\end{array}$ & $\begin{array}{l}\text { Hotel } 3 \\
\text { - Hudson Hotel } \\
\text { - Marriott Downtown } \\
\text { - N.Y. Palace Hotel }\end{array}$ \\
\hline
\end{tabular}

Fig. 4. List of facilities

は，ユーザが利用目的を選択するのに不便を感じないよう， ある程度高い精度を実現することとした。

〈5・2〉 システム評価実験＼cjkstart本節では, 提案システム を用い，ユーザが施設を利用するか否かの意思決定を短時 間で自信を持って（あるいは納得して）行うことができた か否かを検証する。

$\langle\mathbf{5} \cdot \mathbf{2} \cdot \mathbf{1}\rangle$ 実験の方法 本実験における, ユーザのシ ステムの利用状況は, 外出時にその日の行動（昼時や，午 後の夕方まで, 夕方以降などの数時間を想定）を短時間で 決めるというものである。OpenMind は英語で記述されて いるため, 施設利用に用いるコンテンツも英語で書かれて いる必要がある。そこで, 実験ではニューヨークの観光施 設を対象とする。具体的には, ホテル, 博物館, レストラ ン, ショップ, 教会, 公園の 6 種類を取り上げ, 各種類ごと に 3 つの地理施設を選択候補として用意する (図 4 参照)。 被験者は，3つの選択候補の中から自分の利用目的に合っ ていると思われるものを一つ選択する。被験者は，合計 15 回このタスクを行う。ホテルと博物館, レストラン, ショッ プについては, 複数回分の組み合わせを用意している。ホ テルに関しては，3つの選択候補の選び方により，意思決 定の簡単さが異なってくる恐れがあるため, なるべく有名 なものを選んだ。これにより, 価格の差や, 体験談や評判 の書かれたブログの量の差の均一化を図った。

実験では，ユーザは現実世界に自らを位置づけ，その元 で何らかの潜在的な目的を持っていてもらいたい。そこで, あらかじめ, 旅行の種類 (観光, 仕事), 同行者の詳細 (人 

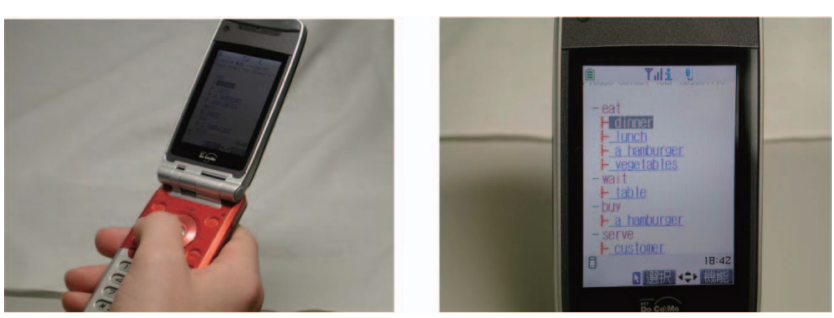

Fig. 5. Accessing by i-mode in the experiment

数とつながり), 利用時間带 (正午, 午後から夕方, 夕方以 降）を決めておいてもらった。これらは地理施設の種類ご とに設定する。

ユーザはi-mode を備えた携帯電話により，システムに アクセスする（図 5 参照）。ユーザは着席した状態で，情 報閲覧を行った。なお，実験では英語コンテンツにアクセ スするため，ユーザには実験前に TOEIC のスコアを提示 してもらい（6段階で選択してもらっている），ある点数に 満たなかったユーザのデータは除外している。これにより， 英語力の差が実験結果に大きく影響を与えてしまうことを 回避している。細かい英語力の違いは残るが，実験中の観 察では，英語力の差が大きくブラウジングに影響している ようには思えなかったため，この方針を採ることとした。

本システムの特徴は，(i) 施設の利用目的を提示すること で検索にユーザの利用目的を選択式で入力できるようにし たこと, (ii) 検索結果の出力に地理施設の利用目的の周辺 テキストを採用したこと，の 2 点である。そこで本実験で は，提案システムと以下のシステムの比較を行った。

(1) Technorati：商用の Blog 検索エンジンである Technorati から, 検索クエリの入力インタフェース と，検索結果のランキング部分のみを抜き出したも のである。ただし，施設名はユーザが図 1 左の画面 で選択式で入力したものを，あらかじめ入力フォー ムに入力している。ユーザはさらに施設の利用目的 を, 携帯電話から直接にテキストで打ち込む必要が ある。本研究では, 従来手法 (ベースライン) と捉 えている。ユーザは Technorati の検索結果の画面 で，スニペットを確認し，さらにリンク先のページ の内容を確認することができる。

(2) Technorati(Obj)：上記の Technorati において, 地理施設と利用目的の入力は提案システムと同じ方 法を用いている。

（3）Snippet：地理施設と利用目的の入力方法は提案シ ステムと同じで, 出力は NRT を出力する変わりに Technorati のスニペットを表示する。

（4） Full：地理施設と利用目的の入力方法は提案シス テムと同じで, 出力は Blog 記事の本文全体を表示 する。

なお, 提案システム (NRT), Snippet, Full では, リン ク先の Blog 記事を読むことはできない。

実験は，3回（各回を「ラウンド」と呼ぶ）行われる。
ユーザは, 各ラウンドにて, NRT, Technorati, Techno$\operatorname{rati}(\mathrm{Obj})$, Snippet, Full の 5 種類のシステムを試す。その ため, 各ラウンドで 5 種類の施設集合を用意している。各 ユーザは，各システムごとに異なる施設集合で実験を行う。 なお，ユーザごとに各システムで用いる施設集合を変える ことで, カウンターバランスを図る。

ユーザは実験後に，自分の施設選択に関する自信の程度 (または納得の程度), 各システムに対する手間の度合いを, それぞれ 5 段階（1：自信なし〜 5 ：自信あり，1：手間がか かる〜 5: 手間がかからない) で提示してもらった。これら は，各ユーザの主観でつけてもらった。また，意思決定ま での時間も計測した。時間の計測には, システムの通信に 要した待ち時間は除外している。全ての実験が終わった後, 上記自信の程度と手間の度合いについては，回答した度合 いについての理由を口頭で尋ねている。被験者は, 大学生 と大学院生の合計 10 名（女性 3 名, 男性 7 名）である。本 実験でのタスクは, B log の情報を読みどの施設を選択する かという, 高度な意思決定を要するものであるため, 統計 的な有意差を求めるためにはより多くの被験者数が求めら れる。そこで, 実験中での観察と実験後のインタビューに より, 結果に対する確かさを確認し, その結果に至った理 由を推測することとする。

$\langle\mathbf{5} \cdot \mathbf{2} \cdot \mathbf{2}\rangle$ 実験結果 表 3 に意思決定に要した時間，表 4 に選択の自信の程度，表 5 に手間の度合いの結果をそれ ぞれ示す。各ユーザの結果と合わせて, 平均值と標準偏差 も示す。

まず, 時間に関しては, Snippet, NRT, Technorati(Obj), Technorati, Full の順で小さかった。Full はブログ記事全 体が表示されるため, 記事全体を読んだり，どこに目的の 情報があるのかを探すのに時間がかかっている様子であっ た。Technoratiは, 利用目的を入力するユーザと, ほとん ど入力しないユーザに分かれたため, 標準偏差が大きくなっ ている。具体的にはユーザ $3,8,9$ がほとんど利用目的を 入力しないユーザであったが，これらのユーザを除くと，8 分 53 秒となり，かなり時間がかかっていることが分かる。

次に，自信の程度であるが，Full，Technorati(Obj)， NRT, Technorati, Snippetの順で高かった。ほほ時間での 順序と逆の関係になっている。情報獲得にかけた時間の影 響が大きいようではあるが, 個別の意見では, 特に Snippet は前後の文脈が分かりにくく，判断が難しかったことが多 く挙げられていた。Snippet は意思決定そのものは早かっ たものの，実際には判断が難しい様子であった。

最後に，主観としての手間の度合いであるが，これも Snippet, NRT, Technorati(Obj), Technorati, Full の順 で高い評価が得られた。これは, 時間での順序と同じになっ ている。個別の意見では, Technorati は目的の入力に何の サポートもないこと, Full は目的の情報を探すのに苦労す ることが，問題として挙げられていた。

時間・手間と, 意思決定の自信の程度が, ほぼトレード オフの関係になっており,この結果からシステム間の優劣 
Table 3. Time for decision making in Experiment 1

\begin{tabular}{|c|c|c|c|c|c|c|c|c|c|c|c|c|}
\hline & User 1 & User 2 & User 3 & User 4 & User 5 & User 6 & User 7 & User 8 & User 9 & User 10 & Average & SD \\
\hline NRT & $6: 35$ & $3: 59$ & $6: 50$ & $4: 55$ & $6: 01$ & $8: 16$ & $9: 57$ & $8: 51$ & $7: 37$ & $6: 12$ & $6: 55$ & $1: 42$ \\
\hline Technorati & $13: 02$ & $7: 28$ & $5: 18$ & $11: 33$ & $7: 45$ & $9: 45$ & $12: 12$ & $3: 19$ & $5: 21$ & $9: 24$ & $8: 31$ & $3: 04$ \\
\hline Technorati(Obj) & $10: 11$ & $7: 10$ & $4: 49$ & $9: 12$ & $7: 11$ & $10: 22$ & $10: 18$ & $7: 17$ & $9: 50$ & $4: 58$ & $8: 08$ & $2: 02$ \\
\hline Snippet & $5: 10$ & $3: 44$ & $4: 10$ & $6: 32$ & $3: 23$ & $6: 13$ & $6: 45$ & $3: 01$ & $7: 51$ & $6: 48$ & $5: 22$ & $1: 36$ \\
\hline Full & $9: 08$ & $5: 10$ & $7: 33$ & $10: 22$ & $10: 21$ & $11: 09$ & $7: 12$ & $9: 45$ & $8: 02$ & $7: 45$ & $8: 39$ & $1: 44$ \\
\hline
\end{tabular}

Table 4. Confidence of decision making in Experiment 1

\begin{tabular}{|c|c|c|c|c|c|c|c|c|c|c|c|c|}
\hline & User 1 & User 2 & User 3 & User 4 & User 5 & User 6 & User 7 & User 8 & User 9 & User 10 & Average & SD \\
\hline NRT & 2.7 & 1.7 & 2.3 & 1.7 & 3.7 & 2.7 & 3.3 & 1.7 & 2.7 & 1.7 & 2.40 & 0.70 \\
\hline Technorati & 3.0 & 2.3 & 2.0 & 2.7 & 1.7 & 2.7 & 2.7 & 2.0 & 1.7 & 2.7 & 2.33 & 0.45 \\
\hline Technorati(Obj) & 3.0 & 2.7 & 2.3 & 3.0 & 2.0 & 3.3 & 3.3 & 2.3 & 3.0 & 2.7 & 2.76 & 0.42 \\
\hline Snippet & 1.7 & 1.3 & 1.3 & 2.7 & 1.0 & 2.7 & 2.0 & 1.7 & 1.7 & 1.7 & 1.77 & 0.52 \\
\hline Full & 2.3 & 1.7 & 3.3 & 4.3 & 3.0 & 3.7 & 2.0 & 2.7 & 1.7 & 3.7 & 2.83 & 0.87 \\
\hline
\end{tabular}

Table 5. Effort for decision making in Experiment 1

\begin{tabular}{|c|c|c|c|c|c|c|c|c|c|c|c|c|}
\hline & User 1 & User 2 & User 3 & User 4 & User 5 & User 6 & User 7 & User 8 & User 9 & User 10 & Average & SD \\
\hline NRT & 3 & 5 & 3 & 4 & 3 & 4 & 3 & 3 & 3 & 4 & 3.50 & 0.67 \\
\hline Technorati & 1 & 2 & 4 & 2 & 3 & 2 & 1 & 4 & 4 & 2 & 2.50 & 1.12 \\
\hline Technorati(Obj) & 3 & 3 & 5 & 3 & 3 & 2 & 2 & 3 & 3 & 4 & 3.10 & 0.83 \\
\hline Snippet & 4 & 5 & 4 & 3 & 4 & 4 & 3 & 5 & 3 & 4 & 3.90 & 0.70 \\
\hline Full & 2 & 3 & 2 & 1 & 1 & 2 & 2 & 1 & 2 & 2 & 1.80 & 0.60 \\
\hline
\end{tabular}

Table 6. Confidence of decision making in Experiment 2

\begin{tabular}{|c|c|c|c|c|c|c|c|c|c|c|c|c|}
\hline & User 1 & User 2 & User 3 & User 4 & User 5 & User 6 & User 7 & User 8 & User 9 & User 10 & Average & SD \\
\hline NRT & 3.3 & 1.7 & 2.7 & 2.3 & 2.7 & 1.7 & 3.0 & 1.7 & 2.7 & 2.7 & 2.43 & 0.56 \\
\hline Technorati & 2.3 & 1.3 & 2.3 & 1.0 & 1.7 & 2.0 & 1.7 & 2.0 & 2.3 & 2.0 & 1.87 & 0.43 \\
\hline Technorati(Obj) & 2.7 & 2.3 & 2.3 & 1.3 & 2.3 & 3.3 & 1.7 & 2.7 & 2.3 & 2.0 & 2.30 & 0.53 \\
\hline Snippet & 1.7 & 2.0 & 2.3 & 1.3 & 2.3 & 1.0 & 2.0 & 1.7 & 1.3 & 1.3 & 1.70 & 0.43 \\
\hline Full & 1.7 & 1.0 & 2.7 & 1.7 & 2.7 & 1.3 & 1.3 & 2.7 & 2.0 & 1.0 & 1.80 & 0.64 \\
\hline
\end{tabular}

を比較することは困難である。今回の実験で，実際に情報 獲得していた時間を見ると, 平均では 5 分 22 秒から 8 分 39 秒ほどかかっている。被験者の様子を見ていると，意思 決定の決め手となるような重要なブログがないかどうかを, 慎重に見定めているように思われた。この実験では，被験 者は室内で着席状態で行ったのであるが，ユーザの情報獲 得に対する取り組み方は，デスクトップ環境とあまり変わ らなかったように思われた。

$\langle\mathbf{5} \cdot \mathbf{2} \cdot \mathbf{3}\rangle$ 統制実験とその結果 前述の実験に対して, もう少し外出時の情報獲得の環境に近くなるよう統制をか けて，再実験を行うこととした。再実験では，5分という 上限を設け，着席せずに立った状態で，システムを使用し てもらった。また，「正確に意思決定することよりも，短時 間にある程度納得のいく意思決定ができれば良い」という 認識の元で実験に取り組んでもらうよう指示した。これに より, 外出時に早く次の目的地を決めたいという要求を模 擬することとした。

前述の実験とは異なる別の 10 人のユーザに被験者となっ てもらった。被験者は, 大学生と大学院生の合計 10 名（女 性 3 名, 男性 7 名）である。評価指標は, 実験後に尋ねた施 設の選択に関する自信の程度と, システムに対する主観的 な手間の度合いである。時間に上限を設けているため，意
思決定できなかった場合をワーストケースと捉え, 施設の 選択に関する自信の程度を 6 段階とし，(0：意思決定でき なかった， 1 ：自信なし〜 5：自信あり）とした。また，実 世界での情報収集において，どのシステムを最も指示する かについてのアンケートも取った。

自信の程度の結果を表 6 に, 主観的な手間の度合いの結 果を表 7 に示す。自信の程度については, NRT, Technorathi(Obj), Technorati, Full, Snippetの順で良かった。 統制をかけなかった時に高かった Technorati と Technorathi(Obj), Full は值が落ちている。時間が 5 分と短かった ことから，意思決定できなかったケースが, NRT で 1 回, Technorati 3 回, Technorati $(\mathrm{Obj})$ で 2 回, Snippet で 2 回, Full で 5 回発生していた。一方, 手間の度合いに関 しては, Snippet, NRT, Technorati(Obj), Technorati, Full の順で良かった。これは, 統制をかけなかったときと 同じ順である。しかし, 時間の上限があることから, 各ユー ザはシステムの使いやすさの評価に関してよりシビアになっ たようで，いずれのシステムも值を落としている。これら の結果から, 手間の度合いに対して, 自信のある意思決定 のできなかったTechnorati, Technorati $(\mathrm{Obj})$ と Full は, NRT に比べると, 劣っていると言える。Technorati(Obj) は, 統制をかけなかったときには, NRTより良かったが, 
Table 7. Effort for decision making in Experiment 2

\begin{tabular}{|c|c|c|c|c|c|c|c|c|c|c|c|c|}
\hline & User 1 & User 2 & User 3 & User 4 & User 5 & User 6 & User 7 & User 8 & User 9 & User 10 & Average & SD \\
\hline NRT & 5 & 3 & 2 & 4 & 4 & 2 & 3 & 2 & 4 & 4 & 3.30 & 1.00 \\
\hline Technorati & 2 & 2 & 1 & 4 & 1 & 3 & 2 & 3 & 2 & 4 & 2.40 & 1.02 \\
\hline Technorati(Obj) & 3 & 3 & 2 & 4 & 2 & 2 & 3 & 4 & 3 & 3 & 2.90 & 0.70 \\
\hline Snippet & 4 & 4 & 3 & 5 & 3 & 3 & 4 & 3 & 3 & 4 & 3.60 & 0.66 \\
\hline Full & 2 & 2 & 1 & 2 & 1 & 1 & 2 & 2 & 2 & 1 & 1.60 & 0.49 \\
\hline
\end{tabular}

Table 8. The number of users who supported each system

\begin{tabular}{|c|c|c|c|c|}
\hline NRT & Technorati & Technorati(Obj) & Snippet & Full \\
\hline 6 & 1 & 3 & 0 & 0 \\
\hline
\end{tabular}

時間制限のある状況では，十分に元のブログ記事を読むこ とができなかったようである。

しかし，NRT と Snippetを比較すると，自信の程度は NRT の方が高く，手間の度合いは Snippet の方が高くなっ ている。ここでは，依然としてトレードオフの関係が成り 立っている。しかし，手間の度合いの差に比べると，自信の 程度の差の方が大きくなっている。また，ユーザの最も支 持するシステムについての回答を見ると表 8 のようになっ ている。回答数が少ないので，はっきりしたことは言えな いが, NRTが最も指示されている。これらのことから，実 世界での情報獲得においては, Snippetよりも NRT の方 が良いと思われる。

ただし, Technorati と Technorati(Obj)を選択したユー ザもいたことも，無視できない事実である。その理由とし て, 検索のメタファとして慣れ親しんでいる点や, 他のシ ステムよりも自由度が高かい点（目的に関するキーワード を必ずしも入力しなくても良い点や, B $\log$ 本文を必ずしも 見なくても良い点）を挙げていた。これらのことから，従 来と同様の検索ができる自由度を残しつつ，目的を手軽に 入力できるインタフェースを用意し, B $\log$ 本文の重要部分 の抽出結果を見せることが重要であると考える。

最後に，本システムの日本語への対応について考える。 現時点では, 日本語でのオープンな常識データベースが存 在しないため，本システムを日本語に適用することはでき ない。日本語でのオープンな常識データベースは, 英語の ものよりも計算機による可読性が低くなると思われる。な ぜなら，丁寧語や助詞・主語の省略と言った，日本語特有の 問題が存在し, 常識の文章の多様性が高くなるためである。 本システムを日本語に対応するためには，この常識データ ベースの作成においても，記述上の制約を設ける必要があ ると考える。

\section{6. 関連研究}

$\mathrm{PC}$ (あるいはいくつかの想定される端末）用に作成され たページの情報を携帯端末用にフィルタリングする方式に ついて紹介する。

最も簡単な方式に, StretchTextがある。StretchTextの 基本的な考え方は, 適応型ハイパーテキストの研究分野 (17)
で始まった (18)(19)。文書をいくつかの部分に分割しておき, ユーザの興味や理解度に応じて, 表示するか否かを選択す るというものである。Cooper らは，この考えをPDAでの Web ページ表示に応用している ${ }^{(20)}$ 。文書を複数の塊に分 割しておき，その分割に要約のレベルを人手で設定してお く。ユーザがその要約のレベルを指定すれば，そのレベル より一般的な内容の塊だけが見られるという方式である。

また，他の簡単な方式には，携帯端末の種類に応じて， 同じ内容でも異なる表現形式のコンテンツを事前に用意し ておき，アクセス時にユーザの興味と携帯端末の種類を判 断して，そのコンテンツを組み合わせて送信するものもあ る(21)。また，組織内の情報共有を目的としたシステムで, 端末の種類だけではなく, 位置やグループ内での役割など も考慮して, 適切な情報のみ携帯端末に送るシステムも提 案されている(22)。

上記の方式は，事前に携帯端末用のコンテンツを用意し ておく必要があるが，既存の HTML 文書を携帯端末用に， 情報をフィルタリングし，表現形式を変換するものもある。 Bickmore らは, ページの縮約技術とページ部分のフィル タリング技術を組み合わせたシステムを開発している ${ }^{(23) 。 ~}$ ページの縮約は文書構造に関する情報を利用している。フィ ルタリングは, 文書の構造の情報に加えて, テキストに対 する簡単な正規表現を利用して, 表示する文書部分を決定 している。具体的な決定方式はエンドユーザがスクリプト 言語で記述することを想定している。

また, Hattoriらは, 携带端末からのWeb 検索を対象に, 実世界のコンテキストを元にクエリを修正する方式をいく つか提案している。一つ目の提案では, GPS の緯度経度情 報から，GISの情報により場所の名前を特定し，その場所 に応じた activitiy（行動）の名前を保管している ${ }^{(24)}$ 。場所 の名前に対する行動は, ブログマイニング ${ }^{(25)}$ により行っ ている。二つ目の提案では, 一つ目の提案同様にクエリの 修正を試みているが，より階層的に修正できるようにして いる ${ }^{(26)}$ 。具体的には, 最初の数文字を打てば, 単語の予測 を行ってくれる入力補助と, 入力クエリに関連するサブト ピックの提示, 入力クエリに対する比較キーワードの提示, を順番に行ってくれる。Yauらも, 携带端末からの情報検 索において，クエリ修正を試みている(27)。彼らは長期の ユーザプロファイルと現在のコンテキストに基づいて，修 正を行っている。

我々の研究は，事前に携帯端末用のコンテンツを用意し ておくのではなく, 既存の HTML 文書から携带端末用に 情報をフィルタリングしている。Bickmore らの研究とは 
異なり，位置情報に応じて情報のフィルタリングを行って いる。Hattori らの研究とは非常によく似ている。Hattori らの一つ目の提案では，場所名に応じた行動（利用目的） をWebマイニングにより取得しているが，我々の研究では オープンな常識データベースである OpenMind から取得し ている。Web 全体を対象とするよりも，より正確に行動や 利用目的を取得できると思われる。二つ目の提案では，入 カクエリに関連するサブトピックの提示が, 我々の研究に おける利用目的の提示に近い。彼らはサブトピックの提示 をクエリログにおける共起語から行っている。ただし，ク エリに並列に入れる語は，具体的なインスタンス名や同位 語など，必ずしも行動や利用目的に関するものではない。 また, Hattoriらの研究はクエリの修正に留まるが, 我々の 研究ではクエリ周辺のテキスト部分を抽出して提示してい る。すなわち, 我々の研究と従来研究との違いは, 我々の 研究は地理施設の利用目的をより的確に取得し, クエリ修 正だけでなく，携帯端末の表示用に，利用目的に関連する 部分のみ抽出している点にあると言える。

\section{7. おわりに}

我々は，実世界を散策中のユーザに対し，興味を持った 地理施設に関する Blog 記事を携帯端末を通じて提供するシ ステムを開発した。本システムでは，ユーザが興味を持っ た地理施設の利用目的を入力できるようにし，その利用目 的に応じた B log 記事を出力するようにした。ここで，利用 目的を選択式で入力できるようにするために，事前に常識 データベース（Open Mind）から利用目的に関する情報を 獲得し, それを「動詞 $\rightarrow$ 名詞句」の階層構造で表示するよ うにした。地理施設名と利用目的をキーワードとして Blog 記事を検索し，利用目的の周辺テキストのみ出力すること とした。

評価実験では, 提案システムに加えて, 従来の B $\log$ 検索 エンジンからクエリの入出力 IF のみを実装したもの (Technorati), 上記の入力方式を提案システムと同じにしたもの (Technorati $(\mathrm{Obj}))$, NRT の代わりに従来のスニペットを 提示するもの (Snippet), NRTの代わりにBlog 記事全体 を提示するもの (Full) と比較を行った。立席状態で時間 に制約を設けた状況で実験を行った結果, Technorati と, Technorati(Obj), Full は, 手間の度合いに比較して, 地 理施設の選択の自信の程度が低く，提案システムの方が優 れていることが確認された。Snippetは，提案システムよ り手間はかからないものの, それ以上に自信の程度が低く なっており，やはり提案システムの方が優れていることが 確認された。

外出時に携帯電話での情報獲得に割くことのできる時間 や手間については，個人差や状況による差があると思われ る。短時間で閲覧可能な分量の情報を提示するような情報 獲得と, もう少し長い時間をかけて詳細を確認できるよう な情報獲得とを, シームレスにつなぐような情報検索イン タフェースが必要であると考える。今後は, このようなイ
ンタフェースの開発を進める予定である。

謝 辞

本研究の一部は，セコム科学技術振興財団の支援を受け て行われました。

(平成 21 年 6 月 1 日受付, 平成 21 年 11 月 30 日再受付)

\section{文献}

(1) B.D. Gordon: "Anytime/anyplace computing and the future of knowledge work", Communications of ACM, Vol.45, No.12, pp.67-73 (2002)

(2) A.N. Dragunov, et al.: "Tasktracer: A Desktop Environment to Support Multi-Tasking Knowledge Workers", Proc. of IUI'05, pp.41-50 (2005)

(3) E. Horvitz, et al.: "The Lumiere Project: Bayesian User Modeling for Inferring the Goals and Needs of Software Users", Proc. of UAI'98, pp.256-265 (1998)

(4) T. Fawcett and F. Provost: "Activity Monitoring: Notice Interesting Changes in Behavior", Proc. of KDD'99, pp.53-62 (1999)

(5) M. Philipose, et al.: "The Probabilistic Activity Toolkit: Towards Enabling Activity-aware Computer Interfaces", Technical Report IRS-TR-03-013, Intel Research Lab (2003)

(6) M. Dredze, T. Lau, and N. Kushmerick: "Automatically Classifying Emails into Activities", Proc. of ACM IUI'06, pp.70-77 (2006)

(7) J. Shen, L. Li, T.G. Dietterich, and J.L. Herlocker: "A Hybrid Learning System for Recognizing User Tasks from Desktop Activities and Email Messages", Proc. of ACM IUI'06, pp.86-92 (2006)

(8) OpenCyc: http://www.cyc.com/

(9) Open Mind: http://commonsense.media.mit.edu/opensourcecommonsense.html

(10) M. Kamvar and S. Baljua: "A Large Scale Study of Wireless Search Behavior: Google Mobile Search", Proc. of ACM CHI'06, pp.701-709 (2006)

(11) B.Q. Hung, M. Otsubo, Y. Hijikata, and S. Nishida: "Extraction of Semantic Text Portion Related to Anchor Link", IEICE Trans. of Information and Systems, Vol.E89-D, No.6, pp.1834-1847 (2006)

(12) Document Object Model (DOM), http://www.w3.org/DOM/

(13) GML - the Geography Markup Language: http://www. opengis.net/gml/

(14) http://www.wordsmyth.net/

(15) http://www.w3.org/TR/1998/NOTE-compactHTML-19980209/

(16) http://technorati.com/

(17) P.L. Brusilovsky: "Methods and Techniques of Adaptive Hypermedia, User Modeling and User-Adapted Interaction", Vol.6, No.2-3, pp.87-129 (1996)

(18) C. Boyle and A.O. Encarnacion: "MetaDoc: An Adaptive Hypertext Reading System, User Modeling and User-Adapted Interaction", Vol.4, No.1, pp.1-19 (1994)

19) A. Kobsa, et al.: "KN-AHS: An Adaptive Hypertext Client of User Modeling System BGP-MS", Proc. of UM'94, pp.31-36 (1994)

(20) I. Cooper and R. Shufflebotham: "PDA Web Browsers: Implementation Issues", University of Kent at Canterbury Computing Laboratory, B0018R775A (1995)

(21) T. Lemlouma and N. Layaida: "Context-aware Adaptation for Mobile Devices", Proc. of IEEE International Conference on Mobile Data Management, pp.106-111 (2004)

(22) M. Kirsch-Pinheiro: "Context-aware Filtering for Collaborative Web Systems: Adapting the Awareness Information to the User's Context", Proc. ACM SAC'05, pp.1668-1673 (2005)

(23) T. Bickmore, A. Girgensoh, and J.W. Sullivan: "Web Page Filtering and Re-Authoring for Mobile Users", The Computer Journal, Vol.42, No.6 (1999)

(24) S. Hattori, T. Tezuka, and K. Tanaka: "Activity-based Query Refinement for Context-Aware Information Retrieval", Proc. of ICADL 2006 (LNCS 4312), Springer, pp.474-477 (2006)

(25) T. Kurashima, T. Tezuka, and K. Tanaka: "Blog Map of Ex- 
periences: Extracting and Geographically Mapping Visitor Experiences from Urban Blogs", Proc. of WISE'05 (LNCS 3806), pp.496-503 (2005)

(26) S. Hattori, et al.: "ReCQ: Real-world Context-Aware Querying", Proc. of CONTEXT 2007 (LNAI 4635), pp.248-262 (2007)

(27) S.S. Yau, et al.: "Situation-aware Personalized Information Retrieval for Mobile Internet", Proc. of COMPSAC'03, pp.638-645 (2003)

松 辻 智 之 (非会員) 2007 年 3 月, 大阪大学基礎工学部シ

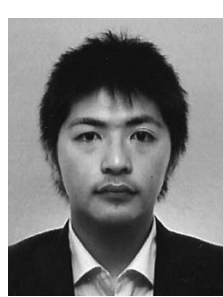
ステム科学科卒業。2009 年 3 月, 同大学大学院 修士課程修了。 2009 年 4 月より, 新日鉄ソリュー ションズ。在学中は, モバイルコンピューティン グの研究に従事。

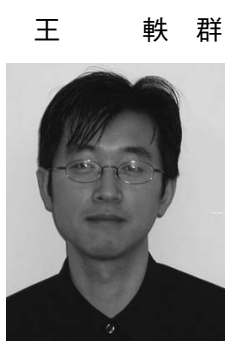

（非会員） 2001 年 3 月, 大阪大学基礎工学部シ ステム科学科卒業。2006 年 3 月, 同大学大学院 博士課程修了。2006 年 4 月より, ダイハツ工業 (株) 電子技術部。在学中は, 時空間データベー スとモバイルコンピューティングの研究に従事。 博士 (工学)。
土 方 嘉 徳 (非会員) 1996 年 3 月, 大阪大学基礎工学部シ ステム工学科卒業。1998 年 3 月, 同大学大学院 修士課程修了。同年, 日本アイ・ビ-・エム (株) 東京基礎研究所入社。2002 年 4 月，大阪大学大 学院基礎工学研究科システム創成専攻助手。2009 年 4 月より, 同准教授。 2003 年電気学会「論文誌 $\mathrm{C}$ 発刊 30 周年記念」特集最優秀論文賞, 2005 年 インタラクション 2005 ベストペーパー賞, 2006 年 ACM IUI Best Paper Award, 各受賞。知的 Web 技術, 情報推 薦, テキストマイニングの研究に従事。情報処理学会, 電子情報通信 学会各会員。博士 (工学)。

西 田 正 吾 （正員） 1974 年 3 月, 東京大学工学部電子工学科

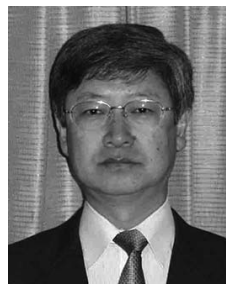
卒業。1976 年 3 月, 同大学大学院修士課程修了。 同年 4 月三菱電機 (株) 入社。同社中央研究所シス テム基礎研究部研究員, グループマネージャーを 経て, 1995 年 4 月, 大阪大学基礎工学部システム 工学科教授。現在, 大阪大学大学院基礎工学研究 科システム創成専攻教授。システム技術，ヒュー マンインタフェース技術, メディア技術の研究に 従事。1984-1985 年 MIT メディアラボ客員研究員。1986 年度, 1993 年度電気学会論文賞, 1992 年度電気学会著作賞, 1995 年度電気学会 進歩賞, 2001 年度ヒューマンインタフェース学会論文賞受賞, 2004 年度電気学会業績賞受賞。電子情報通信学会, 情報処理学会, ヒュー マンインタフェース学会, IEEE ほか会員。IEEE Fellow。著書は, 「ヒューマン・コンピュータ交流技術」(オーム社, 共著),「メディア 工学」(朝倉書店), 「情報メデイア工学」(オーム社, 共著) など。工 学博士。 